\title{
Nondestructive Acoustic Impulse Response Method for Measuring Internal Quality of Apples and Watermelons.
}

\author{
Hiromichi Yamamoto, Mutsuo Imamoto and Shiko Haginuma
}

\author{
National Food Research Institute, Ministry of Agriculture, Forestry and Fisheries. \\ 2-1-2 Kannondai, Yatabe-machi, Tsukuba-gun, Ibaraki-ken 305
}

\begin{abstract}
Summary
Nondestructive internal quality measurement by acoustic impulse response method was examined. Using apples and watermelons, several forms of the acoustic indices were compared with the results of constant speed uniaxial compression tests with cylindrical flesh specimens and sensory ratings. It was found that there were highly significant correlations among acoustic indices, apparent Young's modulus ( $\mathrm{E}_{\text {app }}^{\prime}$ ), breaking stress and sensory firmness.

There were not any significant differences in the internal textural qualities of apples among ripeness classes which were evaluated by external appearance by experts of the fruits. Therefore, it is concluded that this nondestructive method has the advantage of being capable of evaluating internal textural qualities which are difficult to evaluate from external appearance.

The improved method of measuring flesh firmness by means of constant speed uniaxial compression test instead of hand-operated puncture testers has a good effect on the correlation between the acoustic indices and flesh firmness.

For apples, the indices which have more compensation for density than previously proposed indiecs gave increased correlation coefficients with internal textural qualities.

This acoustic impulse response method can be used as a nondestructive internal quality evaluation instead of the mechanical resonance method. The simplicity of this method is of great advantage to practical use.
\end{abstract}

\section{Introduction}

In the previous paper (10), the authors proposed a new method of impulse response sound analysis for measuring natural frequencies of fruits and vegetables. Using apples and watermelons, the natural frequencies of intact fruits were easily determined from the peak frequencies in the power spectrum of impact sound. As a preliminary study of nondestructive measurement of internal textural quality, flesh firmness measured by handoperated puncture testers was compared with the nondestructively obtained acoustic indices and the possibility of nondestructive internal quality evaluation was shown for apples.

Hand-operated puncture testers measure a

Received for publication December 15, 1980 kind of breaking force, however, the breaking force is influenced by the rate of deformation and puncture involves shear in addition to compression (1). Thus the flesh firmness measured in the former paper (10) was not a physically definite value. The low correlation between nondestructive indices and internal quality for watermelons might be attributed to this point of view. So, precise objective measurements of flesh firmness were necessary to confirm the relation between impulse response characteristics and internal textural quality of fruits.

In this paper, the internal textural quality of apples and watermelons was measured more precisely by means of the constant speed uniaxial compression test on cylindrical flesh specimens. From the force-deformation curve of 
the compression test, elastic modulus (apparent Young's modulus), breaking stress and breaking strain were obtained to be compared with acoustic indices $\left(f, m f^{2}\right.$ and $m^{2 / 3} \rho^{1 / 3} f^{2} ; f$ : natural frequency, $m$ : mass, $\rho$ : density) of fruits.

The relation between the ripeness evaluated from external appearance and internal textural quality was also tested for apples to examine the limitation of internal quality evaluation from external appearance.

In addition, considering a new index $m^{a} \rho^{b} f^{2}$ with variable parameter $a$ and $b$, it was examined whether there were any indices which correlated to internal quality much better than $m f^{2}$ and $m^{2 / 3} \rho^{1 / 3} f^{2}$.

\section{Materials and Methods}

A. Test sample

Apples used in this study were from experimental orchards of Nagano Prefectural Horticultural Experiment Station and Aomori Prefectural Apple Experiment Station. Cultivars used were 'Golden Delicious' and 'Starking Delicious'. For each cultivar and production district, 45 fruits were used. The fruits consisted of three classes of ripeness (A : overripe, $\mathrm{B}$ : ripe, $\mathrm{C}$ : preripe). Each class contained 15 fruits. The classification was made by researchers in apple quality in experimental stations from external appearance such as color. Apples from Nagano and from Aomori were harvested on October 15, 1976 and October 25, 1976 respectively. All of the fruits were stored at $0^{\circ} \mathrm{C}$ until they were used for the test. At first measuring time (Nagano 10/19, Aomori 10/29), after nondestructive measurements, 9 (Nagano) or 6 (Aomori) fruits were destructively tested for each class of ripeness. Other fruits were nondestructively tested on $12 / 10,1 / 7,2 / 10$ and $3 / 8$ and destructively tested on $12 / 10$ ( 9 fruits from each cultivar of Aomori), 1/7 (9 fruits from each cultivar of both production districts), and $3 / 8$ (9 fruits from each cultivar of both production districts).

Watermelons used in this study were 'Shi mao' which were harvested on July 28, 1976 from an experimental farm of Miura Branch of Kanagawa Prefectural Horticultural Experiment Station. All of the watermelons were stored at room temperature until the tests were conducted. Nondestructive measurements were made on $7 / 28,7 / 31,8 / 3,8 / 6$ and $8 / 9$, and destructive tests were made on $7 / 29,7 / 30,8 / 4$ and $8 / 10$. On each date of the destructive tests, 14, 13, 14 and 9 watermelons were used respectively.

B. Measuring method of acoustic sound

The way of measurement and analysis of impact sound wave is the same as described in the previous paper (10).

A side of fruit was hit by a wooden ball pendulum $(8.5 \mathrm{~g}$ in weight, $24 \mathrm{~mm}$ in diameter and $84 \mathrm{~cm}$ in length) being swung from the place where the pendulum was at an angle of $40^{\circ}$ to the vertical. The ball pendulum rebounded from fruit instantaniously was caught by hand so that the pendulum might not recontact with the test fruit. The generated acoustic sound (impact sound) was picked up by a condenser microphone and was amplified by a linear amplifier of sound level meter to be recorded on an analog data recorder. The microphone was set on the opposite side of hitting point. The distance between microphone and sample was 3 to $5 \mathrm{~mm}$.

As for apples, the measurement was made on a blushed side and also the opposite side on the equatrial line of each sample which was suspended freely with stem. As for watermelons, one point on the equatrial line of each sample set directly on the table was hit.

A sound signal in the data recorder was reproduced and inputted to a signal analyzer through an $A / D$ converter. After conversion to a digital signal, power spectrum was calculated by means of the fast Fourier transform. The blocksize of data was 1024 and sampling interval was $2 \times 10^{-4} \mathrm{sec}$ for the calculation. Thus, power spectrum in the frequency range from $D C$ to $2500 \mathrm{~Hz}$ with frequency resolution of $4.89 \mathrm{~Hz}$ was obtained.

In the former paper (10), it was confirmed that peak frequencies of power spectrum could be regarded as the natural frequencies of intact fruit except for higher frequency peaks of watermelons. In this paper, peak frequency of apples and the first three peak frequencies of watermelons were analyzed assuming that they were natural frequencies. 


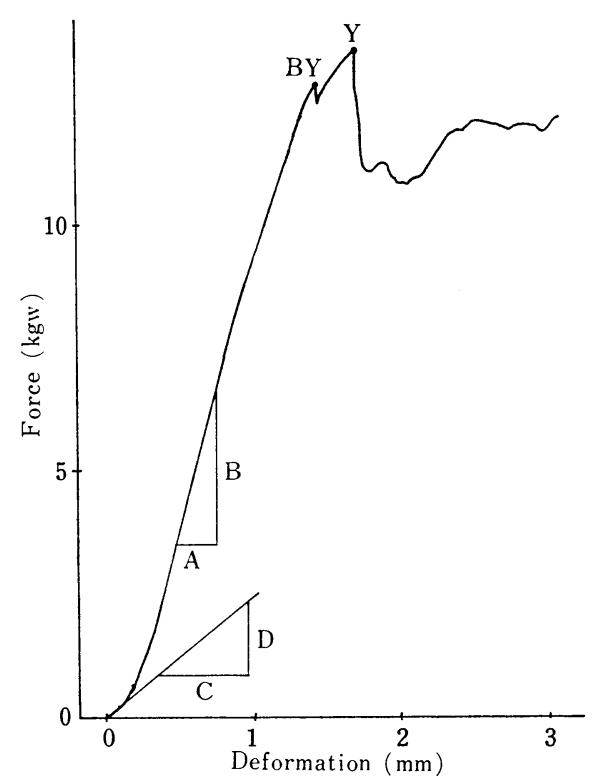

Fig. 1. Typical force-deformation curve for apple. BY : Bioyield point $\mathrm{Y}$ : Yield point (breaking point)

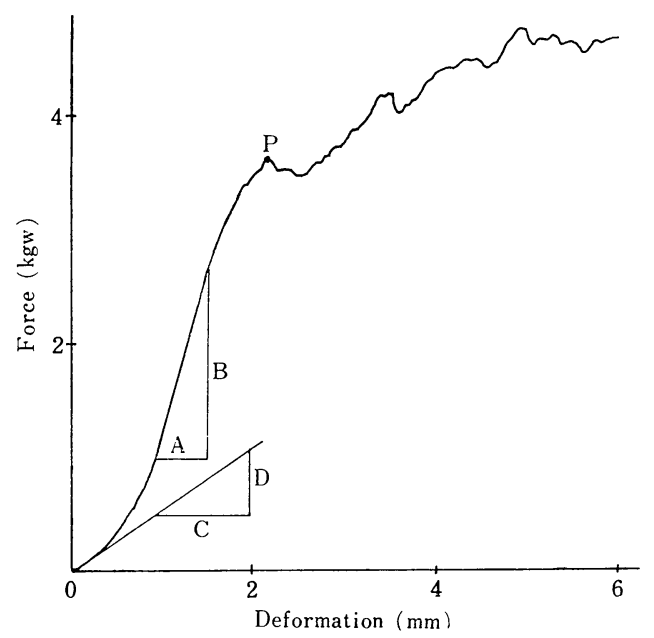

Fig. 2. Typical force-deformation curve for watermelon.

$\mathrm{P}$ : First peak point (breaking point)

C. Objective measurement of flesh firmness

Constant speed uniaxial compression tests were made by Instron type Universal Testing Machine (Shinkoh Tsushin Kogyo Co., TOM 500). A cylindrical flesh specimen having 30 $\mathrm{mm}$ in diameter and $10 \mathrm{~mm}$ in height for apples, and $20 \mathrm{~mm}$ in diameter and $10 \mathrm{~mm}$ in height for watermelons was compressed by a plate mounted on a load cell with a speed of
$10 \mathrm{~mm} / \mathrm{min}$.

Typical force-deformation curves for apple and watermelon are shown in Fig. 1 and Fig. 2. Elastic modulus was calculated from the maximum slope of this curve by the equation

$$
E^{\prime}{ }_{\mathrm{app}}=\frac{B / S}{A / h}
$$

where $h$ is height and $S$ is cross section area of the specimen. The maximum slope (prior to failure) was used by Finney (8) as a measure of flesh firmness. The maximum slope appears in the region where the force-deformation curve is almost linear. This slope is easily defined and free from the difficulty of making cylindrical specimens with strict parallel ends as shown by Bourne (2). However, this slope cannot be assured to represent linear elasticity since the slope appears at a rather large deformation. Thus, the elastic modulus calculated from this maximum slope should not be regarded as real Young's modulus, but should be considered as apparent Young's modulus being designated $E_{\text {app }}^{\prime}$ in equation (1).

In this test, $E_{\text {app }}^{\prime}$ ranged 19 to $44 \mathrm{kgw} / \mathrm{cm}^{2}$ (1. 9 to $4.4 \times 10^{7}$ dyne $\left./ \mathrm{cm}^{2}\right)$ for apples and 5 to $15 \mathrm{kgw} / \mathrm{cm}^{2}$ (5 to $15 \times 10^{6} \mathrm{dyne} / \mathrm{cm}^{2}$ ) for watermelons. Comparing these data for apples with the data of Young's modulus for apple flesh by Finney $(4,5)$, who reported that Young's modulus ranged 4 to $15 \times 10^{7} \mathrm{dyne} / \mathrm{cm}^{2}, E_{\text {app }}^{\prime}$ in this test had the same order as Finney's data although he had measured the modulus as the dynamic modulus of elasticity.

On the other hand, the real Young's modulus $\left(E_{0}{ }^{\prime}\right)$ for elastic material is defined as the slope at infinitesimal deformation of stressstrain curve as follows:

$$
E_{0}{ }^{\prime}=\frac{D / S}{C / h}
$$

However, it was difficult to determine the slope in the region of force-deformation curve because of the non-linearity of the curve which might be affected by non-parallel ends of test specimen and the existence of the plastic deformation of test specimen at initial point of force deformation curve. Thus, the slope at infinitesimal deformation was not used in this test.

Breaking stress was derived from the division of breaking force by the initial cross section 
area. Breaking strain was derived from the division of breaking deformation by the initial specimen height. On the force-deformation curves of biological tissues such as fruits and vegetables, there are commonly two kinds of rupture points, namely, bioyield point and yield point (9). In this compression test, bioyield point does not always appear in the force-deformation curve of apples, and both bioyield point and yield point of watermelons are not clear in most cases, which may be affected by the watery-spongy character of watermelon tissue. Therefore, as shown in Fig. 1 and Fig. 2, yield point was used for apples and the first peak point was used for watermelons as the breaking point for the measure of breaking force and breaking deformation.

The Magness-Taylor test was also made for pared apple flesh by a $11 \mathrm{~mm}$ (7/16 inch) diameter Magness-Taylor's probe mounted on the load cell with a constant speed of $30 \mathrm{~mm} / \mathrm{min}$. The maximum force necessary for the sample to be deformed by $8 \mathrm{~mm}$ was defined as the Magness-Taylor pressure reading. This Magness-Taylor test differs from a commonly used hand-operated test in that a controlled rate of loading is used.

D. Color measurement

Skin color of apples were measured by a color and color difference meter (Tokyo Denshoku Model TC 55D). For each sample, two measurements were done on both the blushed side and the unblushed side on the equatrial line, and the average of the two readings of $a$ value in Hunter's color notation ( $L a b$ ) was used as a degree of redness of the external skin color.

\section{E. Sensory evaluation}

Sensory evaluations were conducted by $5-10$ panelists depending on a measuring date. Flesh firmness was rated on a 5 -point scale, with 5 hard and 1 soft. The procedure of sensory evaluation was the same as the former paper (10).

\section{Results and Discussion}

A. Testing the difference of ripeness classes of apples

Table 1 summarizes the nondestructive and destructive parameters for each ripeness class of apples. There are distinct differences in color among ripeness classes for Aomori Golden Delicious, especially. For Nagano Golden Delicious and Aomori Starking Delicious, C class (preripe) samples showed a significant color difference from other two classes. The differences in density among ripeness classes were shown typically for 'Starking Delicious'.

For Nagano apples, A class (overripe) samples showed significantly high acoustic indices $\left(m f^{2}\right.$ and $\left.m^{2 / 3} \rho^{1 / 3} f^{2}\right)$ as compared with the other two classes. However, this is the inverse to the ordinarily expected tendency that the acoustic indices usually become small as a result of flesh softening paralleling with fruit

Table 1. Mean values of nondestructive and destructive parameters for each ripeness class of apple.

\begin{tabular}{|c|c|c|c|c|c|c|c|c|c|c|c|c|}
\hline & \multicolumn{6}{|c|}{ Golden Delicious } & \multicolumn{6}{|c|}{ Starking Delicious } \\
\hline & \multicolumn{3}{|c|}{ Nagano } & \multicolumn{3}{|c|}{ Aomori } & \multicolumn{3}{|c|}{ Nagano } & \multicolumn{3}{|c|}{ Aomori } \\
\hline & $\mathrm{A}$ & B & $\mathrm{C}$ & A & B & $\mathrm{C}$ & A & $\mathrm{B}$ & $\mathrm{C}$ & $\mathrm{A}$ & $\mathrm{B}$ & $\mathrm{C}$ \\
\hline$m(\mathrm{~g})$ & $284^{\mathrm{a}}$ & $278^{\mathrm{a}}$ & $278^{\mathrm{a}}$ & $307^{a}$ & $301^{\mathrm{ab}}$ & $292^{\mathrm{b}}$ & $277^{\mathrm{a}}$ & $272^{\mathrm{ab}}$ & $263^{\mathrm{b}}$ & $294^{\mathrm{a}}$ & $295^{\mathrm{a}}$ & $303^{a}$ \\
\hline$\rho\left(\mathrm{g} / \mathrm{cm}^{3}\right)$ & $.796^{\mathrm{a}}$ & $.788^{\mathrm{ab}}$ & $.784^{\mathrm{b}}$ & $: 773^{a}$ & $.775^{\mathrm{a}}$ & $.772^{\mathrm{a}}$ & $.895^{\mathrm{a}}$ & $.862^{b}$ & $.838^{c}$ & $.894^{\mathrm{a}}$ & $.872^{\mathrm{b}}$ & $.856^{\mathrm{c}}$ \\
\hline$f(\mathrm{~Hz})$ & $796^{\mathrm{a}}$ & $753^{b}$ & $740^{\mathrm{b}}$ & $781^{\mathrm{a}}$ & $788^{a}$ & $780^{\mathrm{a}}$ & $791^{\mathrm{a}}$ & $745^{\mathrm{b}}$ & $768^{\mathrm{ab}}$ & $771^{\mathrm{a}}$ & $751^{\mathrm{a}}$ & $776^{a}$ \\
\hline$m f^{2}\left(\times 10^{9} \mathrm{~Hz}^{2} \mathrm{~g}\right)$ & $1.80^{\mathrm{a}}$ & $1.57^{\mathrm{b}}$ & $1.52^{\mathrm{b}}$ & $1.87^{\mathrm{a}}$ & $1.87^{\mathrm{a}}$ & $1.87^{\mathrm{a}}$ & $1.73^{\mathrm{a}}$ & $1.51^{\mathrm{b}}$ & $1.55^{\mathrm{b}}$ & $1.74^{\mathrm{a}}$ & $1.66^{\mathrm{a}}$ & $1.82^{\mathrm{a}}$ \\
\hline$m^{2 / 3} \rho^{1 / 3} f^{2}\left(\times 10^{7} \mathrm{H} z^{2} \mathrm{~g} / \mathrm{cm}\right)$ & $2.53^{\mathrm{a}}$ & $2.23^{\mathrm{b}}$ & $2.15^{\mathrm{b}}$ & $2.55^{\mathrm{a}}$ & $2.56^{\mathrm{a}}$ & $2.58^{\mathrm{a}}$ & $2.56^{\mathrm{a}}$ & 2. $22^{\mathrm{b}}$ & $2.29^{\mathrm{b}}$ & $2.53^{\mathrm{a}}$ & $2.39^{\mathrm{a}}$ & $2.58^{\mathrm{a}}$ \\
\hline$a$ (Hunter's color) & $-10.2^{\mathrm{a}}$ & $-10.5^{b}$ & $-13.1^{b}$ & $-6.9^{a}$ & $-9.8^{\mathrm{b}}$ & $-12.8^{c}$ & $22.9^{\mathrm{ab}}$ & $24.1^{\mathrm{a}}$ & $22.1^{\mathrm{b}}$ & $29.5^{\mathrm{ab}}$ & $28.2^{\mathrm{a}}$ & $23.5^{\mathrm{b}}$ \\
\hline Sensory firmness & $3.73^{\mathrm{a}}$ & $3.14^{\mathrm{b}}$ & $4.06^{\mathrm{a}}$ & $2.73^{\mathrm{a}}$ & $3.54^{\mathrm{b}}$ & $4.13^{\mathrm{b}}$ & $3.13^{\mathrm{a}}$ & $3.06^{\mathrm{a}}$ & 3. $79^{a}$ & $3.10^{\mathrm{a}}$ & $3.13^{\mathrm{a}}$ & $3.83^{\mathrm{a}}$ \\
\hline Breaking stress $\left(\mathrm{kgw} / \mathrm{cm}^{2}\right)$ & 4. $01^{\mathrm{a}}$ & 3. $25^{\mathrm{b}}$ & $3.78^{\mathrm{b}}$ & $2.86^{\mathrm{a}}$ & $3.59^{\mathrm{ab}}$ & $3.76^{\mathrm{b}}$ & 4. $10^{\mathrm{a}}$ & $3.86^{\mathrm{a}}$ & 4. $19^{\mathrm{a}}$ & $4.13^{\mathrm{a}}$ & $3.82^{\mathrm{a}}$ & 4. $60^{\mathrm{a}}$ \\
\hline Breaking strain & $.171^{\mathrm{a}}$ & $.190^{\mathrm{a}}$ & $.173^{\mathrm{a}}$ & $.260^{\mathrm{a}}$ & $.256^{\mathrm{a}}$ & $.218^{\mathrm{a}}$ & $.151^{a}$ & $.142^{\mathrm{a}}$ & $.143^{\mathrm{a}}$ & $.155^{\mathrm{a}}$ & $.148^{\mathrm{a}}$ & $.163^{\mathrm{a}}$ \\
\hline $\mathrm{E}_{\mathrm{app}}^{\prime}\left(\mathrm{kgw} / \mathrm{cm}^{2}\right)$ & $35.1^{a}$ & $30.4^{\mathrm{a}}$ & $32.1^{\mathrm{a}}$ & $27.4^{\mathrm{a}}$ & $31.0^{\mathrm{a}}$ & $30.0^{\mathrm{a}}$ & $39.9^{a}$ & $37.2^{\mathrm{a}}$ & $39.4^{\mathrm{a}}$ & $38.1^{a}$ & $35.8^{\mathrm{a}}$ & $38.9^{a}$ \\
\hline Magness-Taylorr (kgw) & $5.85^{a}$ & $4.71^{\mathrm{b}}$ & $5.89^{\mathrm{a}}$ & $4.64^{\mathrm{a}}$ & $5.54^{\mathrm{ab}}$ & $6.53^{\mathrm{b}}$ & $6.49^{\mathrm{a}}$ & $5.70^{\mathrm{a}}$ & $6.22^{\mathrm{a}}$ & $6.44^{\mathrm{a}}$ & $6.41^{\mathrm{a}}$ & $7.36^{\mathrm{a}}$ \\
\hline
\end{tabular}

Small letters indicate mean separation within ripeness classes A, B and C ( $1 \%$ level). 
Table 2. Properties of test fruits at the first measurement after harvest.

\begin{tabular}{|c|c|c|c|c|c|c|c|}
\hline & & & $\begin{array}{c}m \\
(\mathrm{~g})\end{array}$ & $\rho\left(\mathrm{g} / \mathrm{cm}^{3}\right)$ & $\stackrel{f}{f}$ & $\begin{array}{c}m f^{2} \\
\left(\times 10^{7} \mathrm{~Hz} z^{2} \mathrm{~g}\right)\end{array}$ & $\begin{array}{c}m^{2 / 3} \rho^{1 / 3} f^{2} \\
\left(\times 10^{6} \mathrm{~Hz}^{2} \mathrm{~g} / \mathrm{cm}\right)\end{array}$ \\
\hline Apples & $\begin{array}{r}\text { Starking Delicious } \\
\text { Nagano } \\
\text { Aomori } \\
\text { Golden Delicious } \\
\text { Nagano } \\
\text { Aomori }\end{array}$ & $\begin{array}{l}\text { mean } \\
\text { S.D. } \\
\text { mean } \\
\text { S.D. } \\
\text { mean } \\
\text { S.D. } \\
\text { mean } \\
\text { S.D. }\end{array}$ & $\begin{array}{r}270.52 \\
13.92 \\
297.31 \\
17.93 \\
\\
279.92 \\
16.54 \\
299.91 \\
13.14\end{array}$ & $\begin{array}{l}0.865 \\
0.029 \\
0.874 \\
0.020 \\
\\
0.789 \\
0.011 \\
0.774 \\
0.009\end{array}$ & $\begin{array}{r}767.9 \\
39.4 \\
765.6 \\
32.7 \\
\\
762.9 \\
33.9 \\
789.5 \\
29.1\end{array}$ & $\begin{array}{r}15.97 \\
1.55 \\
17.43 \\
1.57 \\
\\
16.31 \\
1.58 \\
18.68 \\
1.03\end{array}$ & $\begin{array}{r}23.53 \\
2.40 \\
24.97 \\
2.10 \\
\\
23.04 \\
2.14 \\
25.63 \\
1.54\end{array}$ \\
\hline
\end{tabular}

\begin{tabular}{|c|c|c|c|c|c|c|c|c|c|c|c|}
\hline & $\begin{array}{c}m \\
(\mathrm{~g})\end{array}$ & $\left(\mathrm{g} / \mathrm{cm}^{3}\right)$ & $\begin{array}{c}f_{1} \\
\left(\mathrm{~Hz}^{2}\right)\end{array}$ & $\begin{array}{c}m f_{1}^{2} \\
\left(\times 10^{7} \mathrm{H} z^{2} \mathrm{~g}\right)\end{array}$ & $\begin{array}{c}m^{2 / 3} \rho^{1 / 3} f_{1}^{2} \\
\left(\times 10^{5} \mathrm{H} z^{2} \mathrm{~g} / \mathrm{cm}\right)\end{array}$ & $\begin{array}{c}f_{2} \\
(\mathrm{~Hz})\end{array}$ & $\begin{array}{c}m f_{2}^{2} \\
\left(\times 10^{7} \mathrm{~Hz}^{2} \mathrm{~g}\right)\end{array}$ & $\begin{array}{c}m^{2 / 3} \rho^{1 / 3} f_{2}{ }^{2} \\
\left(\times 10^{5} \mathrm{~Hz}^{2} \mathrm{~g} / \mathrm{cm}\right)\end{array}$ & $\begin{array}{c}f_{3} \\
\left(\mathrm{~Hz}^{2}\right)\end{array}$ & $\begin{array}{c}m f_{3}^{2} \\
\left(\times 10^{7}\right. \\
\left.H z^{2} \mathrm{~g}\right)\end{array}$ & $\begin{array}{c}m^{2 / 3} \rho^{1 / 3} f_{3}^{2} \\
\left(\times 10^{6}\right. \\
\left.\mathrm{Hz} z^{2} \mathrm{~g} / \mathrm{cm}\right)\end{array}$ \\
\hline $\begin{array}{l}\text { Water- } \\
\text { melons }\end{array}$ & & & & & & & & & & & \\
\hline mean & 6046 & 0.950 & 155.0 & 14.2 & 77.2 & 220.1 & 28.6 & 15.5 & 280.2 & 46.1 & 25.2 \\
\hline S. D. & 1180 & 0.014 & 14.8 & 1.7 & 8.7 & 22.3 & 3.2 & 1.8 & 27.9 & 6.2 & 2.9 \\
\hline
\end{tabular}

ripeness.

On the other hand, objective and sensory measurements of flesh firmness showed hardly any difference in the order of ripeness classes. These results mean that external appearance does not appreciably show the internal quality. It was presumed that external appearance might correspond to internal textural quality only in cases of extremely wide ranges of ripeness. However, the range of ripeness classes in this test was as small as the edibility range, which makes it difficult even for experts to predict internal textural quality by external appearance itself. Thus the classes of ripeness are not used hereafter.

B. Properties and time dependence of nondestructive parameters.

The means and standard deviations of nondestructive parameters for samples at the first test date after harvest are shown in Table 2 . The mean values of $m f^{2}$ for apples are about $1.7 \times 10^{8} \mathrm{~Hz}^{2} \mathrm{~g}$. This is the same order of index $m f_{2}{ }^{2}$ reported as the results of mechanical resonance method by Finney $(5,8)$. From this correspondence, the natural frequency of apples obtained by acoustic impulse response method is assumed to correspond to $f_{2}$ in the mechanical resonance method.

The results of time dependence of natural frequencies for the samples stored till the last of the test period are shown with apples in Fig. 3 and also with watermelons in Fig. 4. Generally speaking, there was a tendency of natural frequencies to shift to a smaller side during the storage period. This tendency was drastically observed in the case of 'Golden Delicious', however, it was not so pronounced in the cases of both 'Starking Delicious' and watermelons. The same tendency had been observed in the test conducted last year (10). It was confirmed that this tendency was affected by the softening of flesh, and the difference of the tendencies between 'Starking Delicious' and 'Golden Delicious' might be characteristic of the cultivar.

C. Relations among acoustic indices and other objective and sensory tests.

Table 3 shows the correlation coefficients between nondestructive and destructive parameters for each cultivar and production district of apples. There are highly significant positive correlations among acoustic indices, sensory firmness, breaking stress, $E^{\prime}$ app and the Magness-Taylor test for each cultivar and production district except for a few cases of 'Starking Delicious' produced in Nagano. The highest correlation coefficient was obtained for Nagano 'Golden Delicious' and the lowest one 


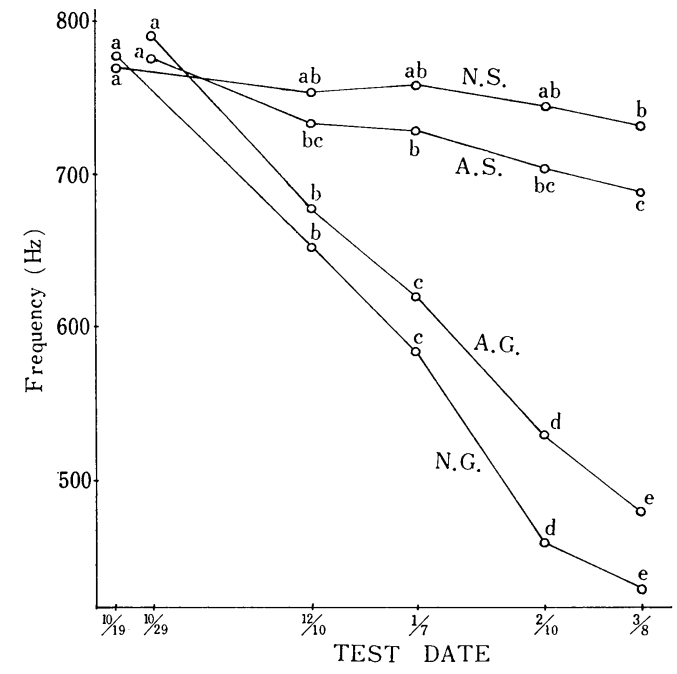

Fig. 3. Time dependence of natural frequencies for apples during storage. (mean values of 9 samples for each cultivar and producing district)

$N$ : Nagano

A : Aomori

G : Golden Delicious

$\mathrm{S}$ : Starking Delicious

Small letters indicate mean separation within one single curve ( $1 \%$ level).

was for Nagano 'Starking Delicious'. There are no significant correlations between breaking strain and acoustic indices except 'Starking Delicious' produced in Aomori.

The compensated indices $m f^{2}$ and $m^{2 / 3} \rho^{1 / 3} f^{2}$ have higher correlations with sensory firmness, $E_{\text {app }}^{\prime}$ and breaking stress than the non-compensated index $f$ alone. These relations are common for both cultivar and production district, showing the effectiveness of compensating the effect of mass and density on the natural frequency. Since the compensated indices $\left(m f^{2}\right.$ and $\left.m^{2 / 3} \rho^{1 / 3} f^{2}\right)$ have a high correlation coefficient with internal qualities $\left(E^{\prime}\right.$ app, breaking stress, etc.) in classes of both cultivar and production district, it is concluded that they are useful for nondestructive internal quality evaluation of apples.

The relation between $m^{2 / 3} \rho^{1 / 3} f^{2}$ and destructive parameter $E_{\text {app }}^{\prime}$ is shown in Fig. 5. Each point is distributed in the similar region regardless of cultivar and production district. There was also the same situation obtained in the relationship between acoustic indices and other destructive parameters such as breaking

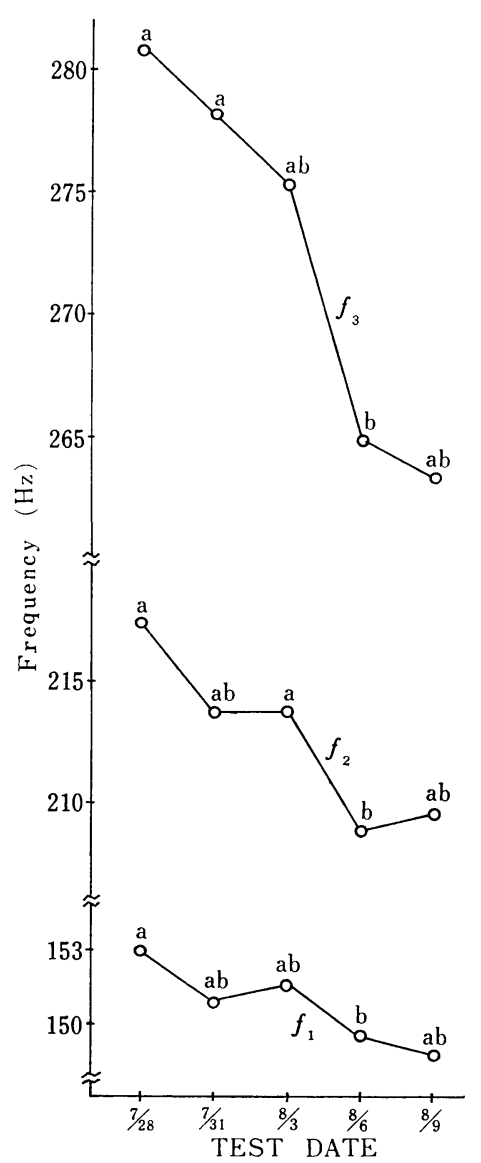

Fig. 4. Time dependence of natural frequencies of watermelons during storage. (mean values of 9 samples)

Small letters indicate mean separation with in one single curve (1\% level).

stress, the Magness-Taylor firmness, etc. These facts show that it is worthwhile to calculate the correlation coefflcients for all samples together as shown in Table 4. There are highly significant correlations between acoustical indices and internal textural qualities such as $E_{\text {app }}^{\prime}$, breaking stress, Magness-Taylor test and sensory firmness. As mentioned previously, the compensated indices $\left(m f^{2}\right.$ and $m^{2 / 3} \rho^{1 / 3} f^{2}$ ) have also higher correlation coefficients in this case than the non-compensated index $f$ alone, which shows that the compensated indices are useful to evaluate an internal quality of apple nondestructively.

For watermelons, on the other hand, correlation coefficients between quality parameters 
Table 3. Correlation coefficients between quality parameters for each cultivar and production district of apple. (1) Aomori Starking Delicious

\begin{tabular}{|c|c|c|c|c|c|c|c|c|c|}
\hline & $\rho$ & $f$ & $m f^{2}$ & $m^{2 / 3} \rho^{1 / 3} f^{2}$ & $\begin{array}{l}\text { Sensory } \\
\text { firmness }\end{array}$ & $\begin{array}{l}\text { Breaking } \\
\text { stress }\end{array}$ & $\begin{array}{l}\text { Breaking } \\
\text { strain }\end{array}$ & $E_{\mathrm{app}}^{\prime}$ & $\begin{array}{l}\text { Magness- } \\
\text { Taylor }\end{array}$ \\
\hline$m$ & 0.308 & -0.133 & 0.197 & 0.105 & 0.220 & 0.204 & -0.172 & 0.309 & 0.194 \\
\hline$\rho$ & & $0.486^{* *}$ & $0.573^{* *}$ & $0.604^{* *}$ & $0.560^{* *}$ & $0.691^{* *}$ & 0.188 & $0.712^{* *}$ & $0.665^{* *}$ \\
\hline$f$ & & & $0.944^{* *}$ & $0.969 * *$ & $0.704^{* *}$ & $0.670^{* *}$ & $0.525^{* *}$ & $0.617 * *$ & $0.663^{* *}$ \\
\hline$m f^{2}$ & & & & $0.993^{* *}$ & $0.775^{* *}$ & $0.735^{* *}$ & $0.455^{*}$ & $0.715^{* *}$ & $0.727^{* *}$ \\
\hline$m^{2 / 3} \rho^{1 / 3} f^{2}$ & & & & & $0.774^{* *}$ & $0.748^{* *}$ & $0.476^{* *}$ & $0.717^{* *}$ & $0.739 * *$ \\
\hline $\begin{array}{l}\text { Sensory } \\
\text { firmness }\end{array}$ & & & & & & $0.940^{* *}$ & $0.540^{* *}$ & $0.846^{* *}$ & $0.943^{* *}$ \\
\hline $\begin{array}{l}\text { Breaking } \\
\text { stress }\end{array}$ & & & & & & & $0.511^{* *}$ & $0.888^{* *}$ & $0.969 * *$ \\
\hline $\begin{array}{c}\text { Breaking } \\
\text { strain }\end{array}$ & & & & & & & & 0.259 & $0.448^{* *}$ \\
\hline$E_{\text {app }}^{\prime}$ & & & & & & & & & $0.881^{* *}$ \\
\hline
\end{tabular}

(2) Aomori Golden Delicious

\begin{tabular}{|c|c|c|c|c|c|c|c|c|c|}
\hline & $\rho$ & $f$ & $m f^{2}$ & $m^{2 / 3} \rho^{1 / 3} f^{2}$ & $\begin{array}{l}\text { Sensory } \\
\text { firmness }\end{array}$ & $\begin{array}{l}\text { Breaking } \\
\text { stress }\end{array}$ & $\begin{array}{l}\text { Breaking } \\
\text { strain }\end{array}$ & $E_{a p p}^{\prime}$ & $\begin{array}{l}\text { Magness- } \\
\text { Taylor }\end{array}$ \\
\hline$m$ & -0.224 & $0.439 *$ & $0.550 * *$ & $0.507^{* *}$ & 0.143 & 0.153 & 0.004 & 0.362 & 0.247 \\
\hline$\rho$ & & 0.100 & 0.085 & 0.107 & 0.174 & $0.374^{*}$ & 0.100 & 0.258 & 0.228 \\
\hline$f$ & & & $0.986^{* *}$ & $0.991^{* *}$ & $0.495^{* *}$ & $0.519^{* *}$ & 0.210 & $0.598^{* *}$ & $0.735 * *$ \\
\hline$m f^{2}$ & & & & $0.999 * *$ & $0.536^{* *}$ & $0.561^{* *}$ & 0.202 & $0.650^{* *}$ & $0.766^{* *}$ \\
\hline$m^{2 / 3} \rho^{1 / 3} f^{2}$ & & & & & $0.543 * *$ & $0.568^{* *}$ & 0.209 & $0.647^{* *}$ & $0.775^{* *}$ \\
\hline $\begin{array}{l}\text { Sensory } \\
\text { firmness }\end{array}$ & & & & & & $0.895^{* *}$ & 0.250 & $0.620^{* *}$ & $0.898^{* *}$ \\
\hline $\begin{array}{l}\text { Breaking } \\
\text { stress }\end{array}$ & & & & & & & 0.269 & $0.665^{* *}$ & $0.886^{* *}$ \\
\hline $\begin{array}{l}\text { Breaking } \\
\text { strain }\end{array}$ & & & & & & & & 0.139 & 0.217 \\
\hline$E_{\mathrm{app}}^{\prime}$ & & & & & & & & & $0.687 * *$ \\
\hline
\end{tabular}

(3) Nagano Starking Delicious

\begin{tabular}{|c|c|c|c|c|c|c|c|c|c|}
\hline & $\rho$ & $f$ & $m f^{2}$ & $m^{2 / 3} \rho^{1 / 3} f^{2}$ & $\begin{array}{l}\text { Sensory } \\
\text { firmness }\end{array}$ & $\begin{array}{l}\text { Breaking } \\
\text { stress }\end{array}$ & $\begin{array}{l}\text { Breaking } \\
\text { strain }\end{array}$ & $E_{a p p}^{\prime}$ & $\begin{array}{l}\text { Magness- } \\
\text { Taylor }\end{array}$ \\
\hline$m$ & $0.392 *$ & -0.169 & 0.337 & 0.218 & 0.058 & 0.231 & -0.110 & 0.368 & 0.229 \\
\hline$\rho$ & & 0.266 & $0.451^{*}$ & $0.511^{* *}$ & 0.377 & $0.656^{* *}$ & -0.378 & $0.680^{* *}$ & $0.667^{* *}$ \\
\hline$f$ & & & $0.868 * *$ & $0.916^{* *}$ & 0.343 & 0.298 & 0.012 & $0.386^{*}$ & 0.341 \\
\hline$m f^{2}$ & & & & $0.986^{* *}$ & 0.350 & $0.398^{*}$ & -0.053 & $0.546 * *$ & $0.440^{*}$ \\
\hline$m^{2 / 3} \rho^{1 / 3} f^{2}$ & & & & & $0.382 *$ & $0.438^{*}$ & -0.081 & $0.565^{* *}$ & $0.482 * *$ \\
\hline $\begin{array}{l}\text { Sensory } \\
\text { firmness }\end{array}$ & & & & & & $0.867^{* *}$ & -0.126 & $0.714^{* *}$ & $0.872^{* *}$ \\
\hline $\begin{array}{l}\text { Breaking } \\
\text { stress }\end{array}$ & & & & & & & -0.251 & $0.884^{* *}$ & $0.949 * *$ \\
\hline $\begin{array}{l}\text { Breaking } \\
\text { strain }\end{array}$ & & & & & & & & -0.350 & -0.234 \\
\hline$E_{a p p}^{\prime}$ & & & & & & & & & $0.827 * *$ \\
\hline
\end{tabular}

are shown in Table 5. Acoustic indices of the first two peaks correlate well to sensory firmness, breaking stress and $E^{\prime}{ }_{\text {app }}$. Indices obtained from the first peak have higher correlation coefficients than those from the second peak. Among these indices, the $m^{2 / 3} \rho^{1 / 3} f_{1}{ }^{2}$ has the highest correlation coefficients with the internal qualities measured destructively. This shows that the index has the capability to compensate for $m$ and $\rho$ in the case of watermelons. Since there are significant correlative relations between acoustic indices, sensory firmness, breaking stress and $E_{\text {app }}^{\prime}$ as well as the results on apples, the acoustic indices can 
(4) Nagano Golden Delicious

\begin{tabular}{|c|c|c|c|c|c|c|c|c|c|}
\hline & $\rho$ & $f$ & $m f^{2}$ & $m^{2 / 3} \rho^{1 / 3} f^{2}$ & $\begin{array}{l}\text { Sensory } \\
\text { firmness }\end{array}$ & $\begin{array}{l}\text { Breaking } \\
\text { stress }\end{array}$ & $\begin{array}{l}\text { Breaking } \\
\text { strain }\end{array}$ & $E_{\text {app }}^{\prime}$ & $\begin{array}{l}\text { Magness- } \\
\text { Taylor }\end{array}$ \\
\hline$m$ & -0.020 & $0.671^{* *}$ & $0.758^{* *}$ & $0.729 * *$ & $0.534^{* *}$ & $0.619^{* *}$ & 0.092 & $0.699 * *$ & $0.611^{* *}$ \\
\hline$\rho$ & & 0.033 & 0.048 & 0.060 & -0.056 & 0.201 & 0.170 & 0.223 & 0.110 \\
\hline$f$ & & & $0.985^{* *}$ & $0.990^{* *}$ & $0.781^{* *}$ & $0.827^{* *}$ & 0.018 & $0.842^{* *}$ & $0.867^{* *}$ \\
\hline$m f^{2}$ & & & & $0.999 * *$ & $0.806^{* *}$ & $0.866^{* *}$ & 0.028 & $0.892^{* *}$ & $0.889 * *$ \\
\hline$m^{2 / 3} \rho^{1 / 3} f^{2}$ & & & & & $0.808^{* *}$ & $0.866^{* *}$ & 0.027 & $0.888^{* *}$ & $0.892^{* *}$ \\
\hline $\begin{array}{l}\text { Sensory } \\
\text { firmness }\end{array}$ & & & & & & $0.902^{* *}$ & -0.057 & $0.853^{* *}$ & $0.931^{* *}$ \\
\hline $\begin{array}{l}\text { Breaking } \\
\text { stress }\end{array}$ & & & & & & & 0.030 & $0.960^{* *}$ & $0.964^{* *}$ \\
\hline $\begin{array}{l}\text { Breaking } \\
\text { strain }\end{array}$ & & & & & & & & 0.032 & -0.064 \\
\hline$E_{\text {app }}^{\prime}$ & & & & & & & & & $0.918^{* *}$ \\
\hline
\end{tabular}

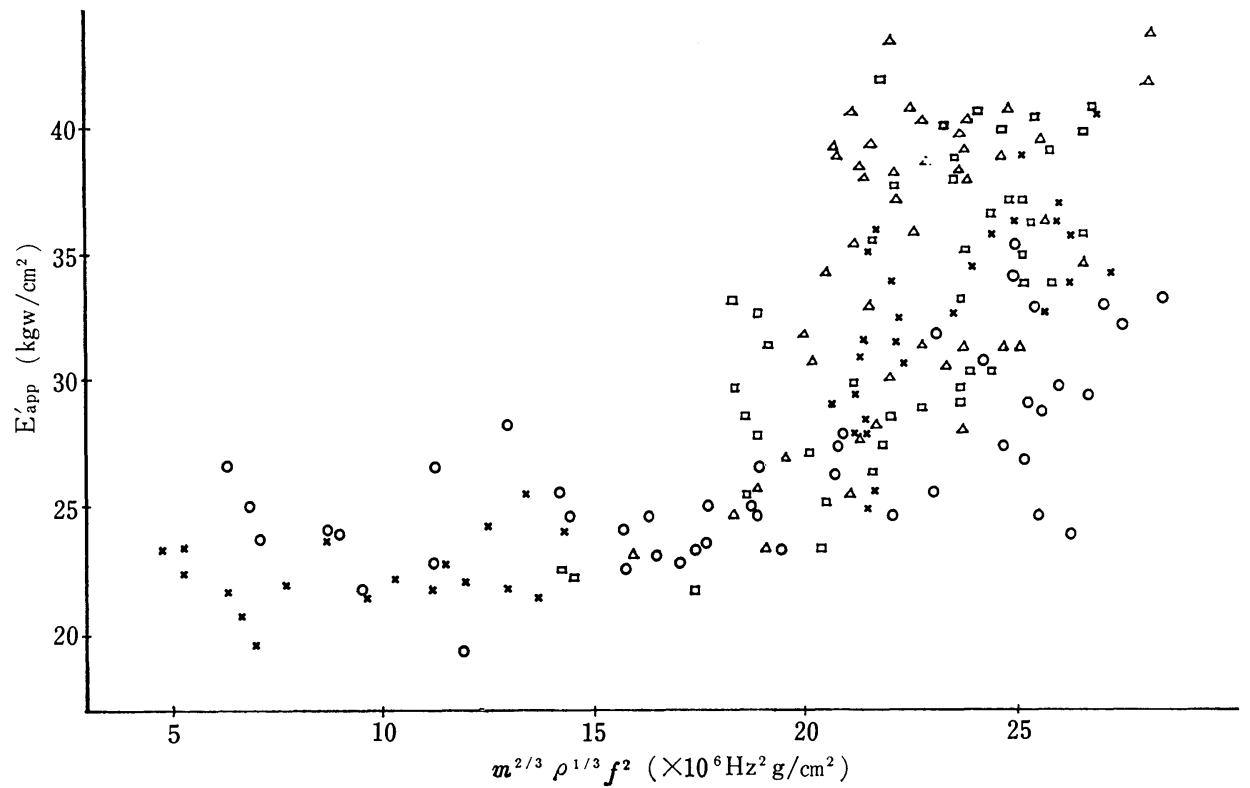

Fig. 5. Scatter diagram of $E_{\text {app }}^{\prime}$ vs. $m^{2 / 3} \rho^{1 / 3} f^{2}$ for all apples.

$\times$.......Nagano Golden Delicious

$\triangle \cdots \cdots$ Nagano Starking Delicious

o......Aomori Golden Delicious

口......Aomori Starking Delicious

be regarded as the firmness index of fruit flesh.

As compared with the previous data of flesh firmness by the hand-operated puncture test (10), the improvement in the measuring method of flesh firmness by the constant rate pressure test gives increased correlation coefficients with acoustical indices, especially with compensated indices. This confirms the validity of compensation by $m$ and $\rho$.
Concerning the relation between sensory firmness and acoustic indices, the previous results that the nondestructive single index $f$ only has a significant correlation with sensory firmness of watermelons (10) does not correspond to these results. This is probably due to the unstableness of sensory rating rather than the limitation of the acoustic impulse response method. The similar result that 
Table 4. Correlation coefficients between quality parameters for all sampless of apples.

\begin{tabular}{l|c|c|c|c|c|c|c|c|c}
\hline \hline & $\rho$ & $f$ & $m f^{2}$ & $m^{2 / 3} \rho^{1 / 3} f^{2}$ & $\begin{array}{l}\text { Sensory } \\
\text { firmness }\end{array}$ & $\begin{array}{l}\text { Breaking } \\
\text { stress }\end{array}$ & $\begin{array}{l}\text { Breaking } \\
\text { strain }\end{array}$ & $E_{\text {app }}^{\prime}$ & $\begin{array}{l}\text { Magness- } \\
\text { Taylor }\end{array}$ \\
\hline$m$ & -0.030 & $0.239^{*}$ & $0.441^{* *}$ & $0.359^{* *}$ & 0.130 & 0.158 & 0.068 & 0.172 & $0.214^{*}$ \\
$\rho$ & & $0.358^{* *}$ & $0.323^{* *}$ & $0.397^{* *}$ & 0.133 & $0.459^{* *}$ & -0.174 & $0.684^{* *}$ & $0.494^{* *}$ \\
$f$ & & $0.968^{* *}$ & $0.983^{* *}$ & $0.498^{* *}$ & $0.530^{* *}$ & 0.061 & $0.654^{* *}$ & $0.663^{* *}$ \\
$m f^{2}$ & & & $0.994^{* *}$ & $0.532^{* *}$ & $0.562^{* *}$ & 0.085 & $0.660^{* *}$ & $0.693^{* *}$ \\
$m^{2 / 3} \rho^{1 / 3} f^{2}$ & & & & & $0.534^{* *}$ & $0.584^{* *}$ & 0.066 & $0.698^{* *}$ & $0.714^{* *}$ \\
$\begin{array}{l}\text { Sensory } \\
\text { firmness }\end{array}$ & & & & & & $0.866^{* *}$ & 0.122 & $0.631^{* *}$ & $0.852^{* *}$ \\
Breaking \\
stress
\end{tabular}

Table 5. Correlation coefficients between quality parameters of watermelons.

\begin{tabular}{|c|c|c|c|c|c|c|c|c|c|c|c|c|c|c|}
\hline & $\rho$ & $f_{1}$ & $m f_{1}^{2}$ & $\left|\begin{array}{r}m^{2 / 3} \rho^{1 / 3} \\
\\
f_{1}^{2}\end{array}\right|$ & $f_{2}$ & $m f_{2}^{2}$ & $\begin{array}{c}m^{2 / 3} \rho^{1 / 3} \\
f_{2}^{2}\end{array}$ & $f_{3}$ & $m f_{3}^{2}$ & $\begin{array}{r}m^{2 / 3} \rho^{1 / 3} \\
f_{3}^{2}\end{array}$ & $\begin{array}{l}\text { Sensory } \\
\text { firmness }\end{array}$ & $\begin{array}{l}\text { Breaking } \\
\text { stress }\end{array}$ & $\begin{array}{l}\text { Breaking } \\
\text { strain }\end{array}$ & $E_{\text {app }}^{\prime}$ \\
\hline$m$ & -.293 & $-.711^{* *}$ & .230 & -.200 & $-.779 * * \mid$ & .200 & -.302 & $-.722 * *$ & .326 & -.186 & -.236 & -.268 & -.195 & -.007 \\
\hline$\rho$ & & $.731^{* *}$ & $.625^{* *}$ & $* \quad .779^{* *}$ & $.578^{* *}$ & $.469 * *$ & $* .642 * *$ & .351 & -.056 & \begin{tabular}{l|l}
6 & .256
\end{tabular} & $.519 * *$ & $* \quad .514^{* *}$ & .118 & $.480^{* *}$ \\
\hline$f_{1}$ & & & $.507^{* *}$ & $.824^{* *}$ & $.934^{* *}$ & $.446^{* *}$ & $.802^{* *}$ & $.785^{* *}$ & .066 & $.522 * *$ & $.592^{* *}$ & $.537^{* *}$ & .092 & $.386^{*}$ \\
\hline$m f_{1}^{2}$ & & & & $.905^{* *}$ & .324 & $.871^{* *}$ & $.739 * *$ & .190 & $.505^{* *}$ & $.497^{* *}$ & $.512^{* *}$ & $.430 *$ & -.105 & $.553^{* *}$ \\
\hline$m^{2 / 3} \rho^{1 / 3} f_{1}^{2}$ & & & & & $.670^{* *}$ & $.790 * *$ & $.880 * *$ & $.506 * *$ & .353 & $.579 * *$ & $.630^{* *}$ & $.557^{* *}$ & -.015 & $.563^{* *}$ \\
\hline$f_{2}$ & & & & & & $.439 *$ & $.823^{* *}$ & $.921 * *$ & .161 & $.645^{* *}$ & $.499 * *$ & $.502^{* *}$ & .139 & .315 \\
\hline$m f_{2}^{2}$ & & & & & & & $.869 * *$ & $.391^{*}$ & $.736 * *$ & $.749^{* *}$ & $.431 *$ & $.423^{*}$ & -.053 & $.523^{* *}$ \\
\hline$m^{2 / 3} \rho^{1 / 3} f_{2}^{2}$ & & & & & & & & $.737^{* *}$ & $.526^{* *}$ & $.807^{* *}$ & $.555^{* *}$ & $.559 * *$ & .046 & $.519 * *$ \\
\hline$f_{3}^{2}$ & & & & & & & & & $359^{*}$ & $.804^{* *}$ & .345 & $.385^{*}$ & .128 & .220 \\
\hline$m f_{3}^{2}$ & & & & & & & & & & $.802^{* *}$ & .109 & .169 & -.128 & .323 \\
\hline$m^{2 / 3} \rho^{1 / 3} f_{3}^{2}$ & & & & & & & & & & & .284 & .350 & .011 & .354 \\
\hline $\begin{array}{l}\text { Sensory } \\
\text { firmness }\end{array}$ & & & & & & & & & & & & $.654^{* *}$ & .064 & $.506^{* *}$ \\
\hline $\begin{array}{l}\text { Breaking } \\
\text { stress }\end{array}$ & & & & & & & & & & & & & .300 & $.788^{* *}$ \\
\hline $\begin{array}{l}\text { Breaking } \\
\text { strain }\end{array}$ & & & & & & & & & & & & & & -.159 \\
\hline
\end{tabular}

sensory firmness of apples does not always significantly correlate to the index $m f^{2}$ was reported by Finney (6).

The correlation coefficients between acoustic indices and destructive parameters are usually significant, however, these are not always high enough for practical use of nondestructive internal quality evaluation, particularly for watermelons. This may be due to the fact that natural frequency obtained acoustically is measured by the infinitesimal deformation of whole fruit, on the other hand, sensory tests and compression tests are measured by the large deformation of a part of whole fruit.
The mechanical characteristics of fruit on the infinitesimal deformation and on the large deformation are not always completely corresponding with each other. In addition, the difference in texture between parts of whole fruit makes it difficult to obtain mean value of sensory and objective measurement for whole fruit because of a nonhomogenious inside.

D. Relations between newly proposed index and other destructive tests.

An analytical approach was conducted to search for optimizing variable parameters $a$ and $b$ in a general form expressed by $m^{a} \rho^{b} f^{2}$ 

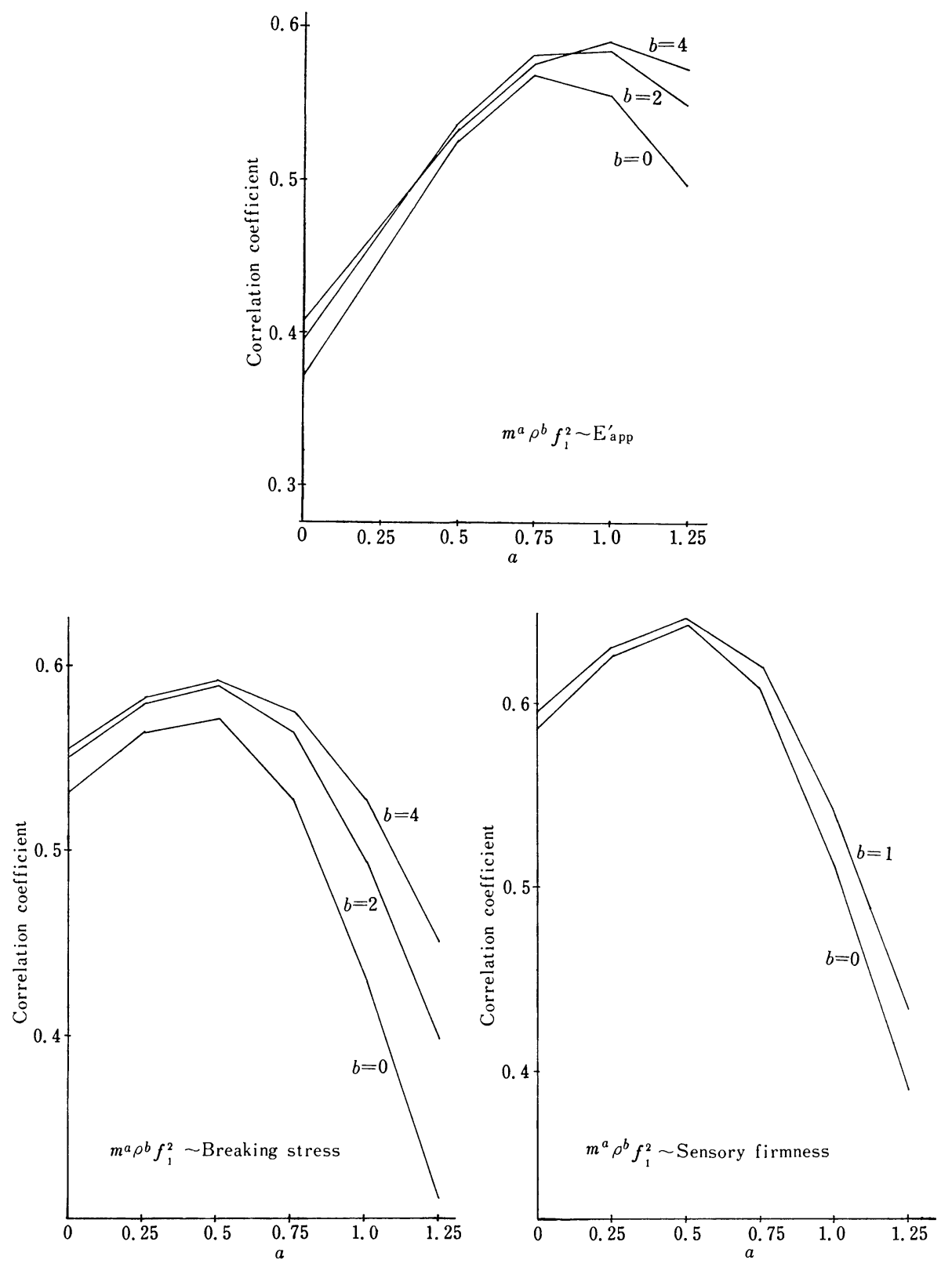

Fig. 6. Variations in the correlation coefficient for watermelons as influenced by $a$ and $b$.

so that the index might compensate for $m$ and $\rho$ to correlate with the internal qualities evaluated destructively.

The index $m f^{2}$ was obtained considering the single-degree-of-freedom spring-mass system and was related to the spring constant of this system (7). However, this one-dimentional model may be not exactly appropriate to real three-dimensional vibration of fruits.

The index $m^{2 / 3} \rho^{1 / 3} f^{2}$ was obtained considering a 3-media elastic sphere model and was related to the shear modulus of fruit flesh (3). It was first used in the form of $m^{2 / 3} f^{2}$ neglecting $\rho^{1 / 3}$.

The newly proposed index $m^{a} \rho^{b} f^{2}$ was merely suggested from the forms of indices 

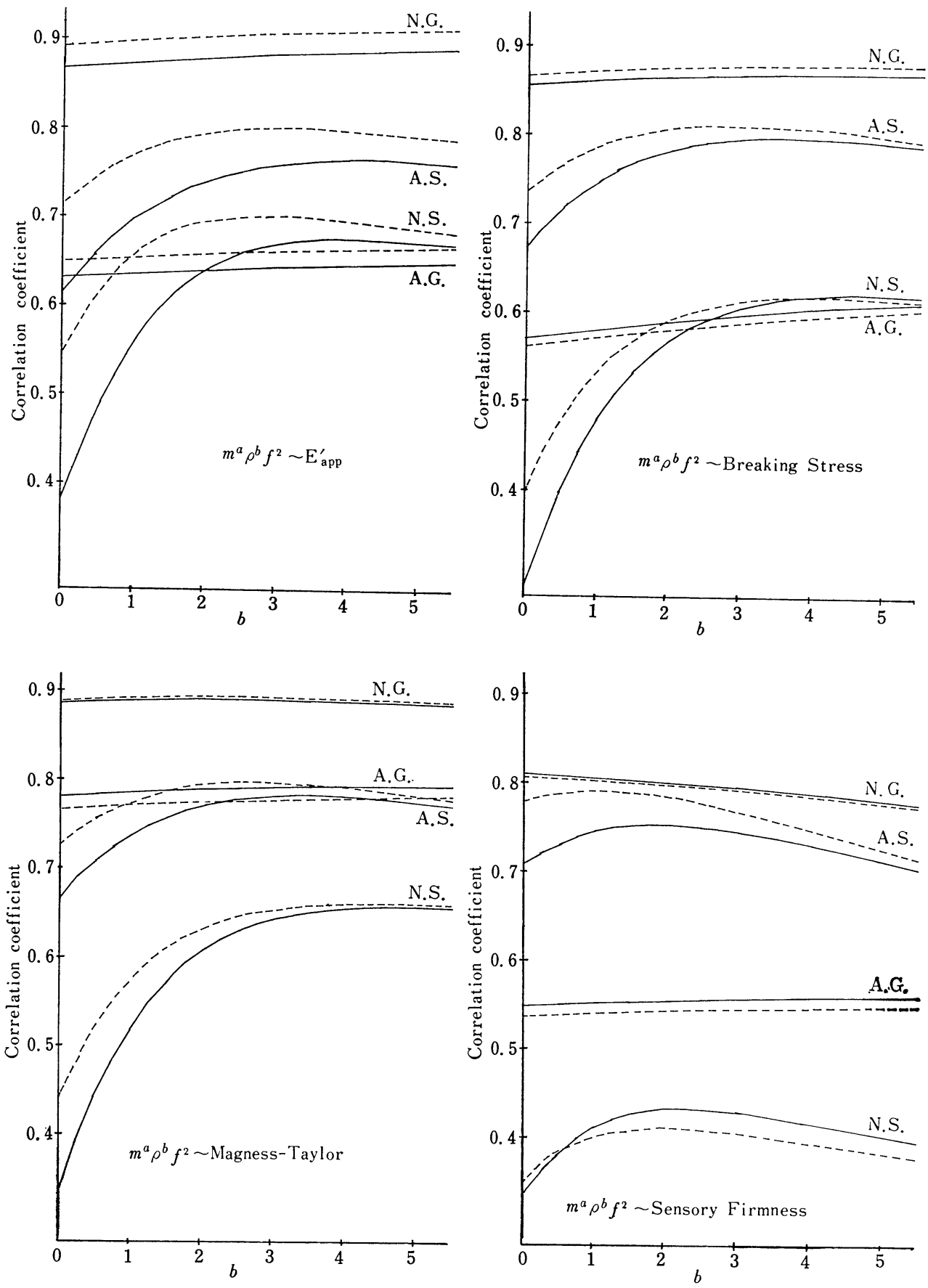

Fig. 7. Variations in the correlation coefficient for apples as influenced by $a$ and $b$.

$\mathrm{N}$ : Nagano

A : Aomori

$S$ : Starking Delicious

G : Golden Delicious

- $a=0$

$\cdots: a=1$ 

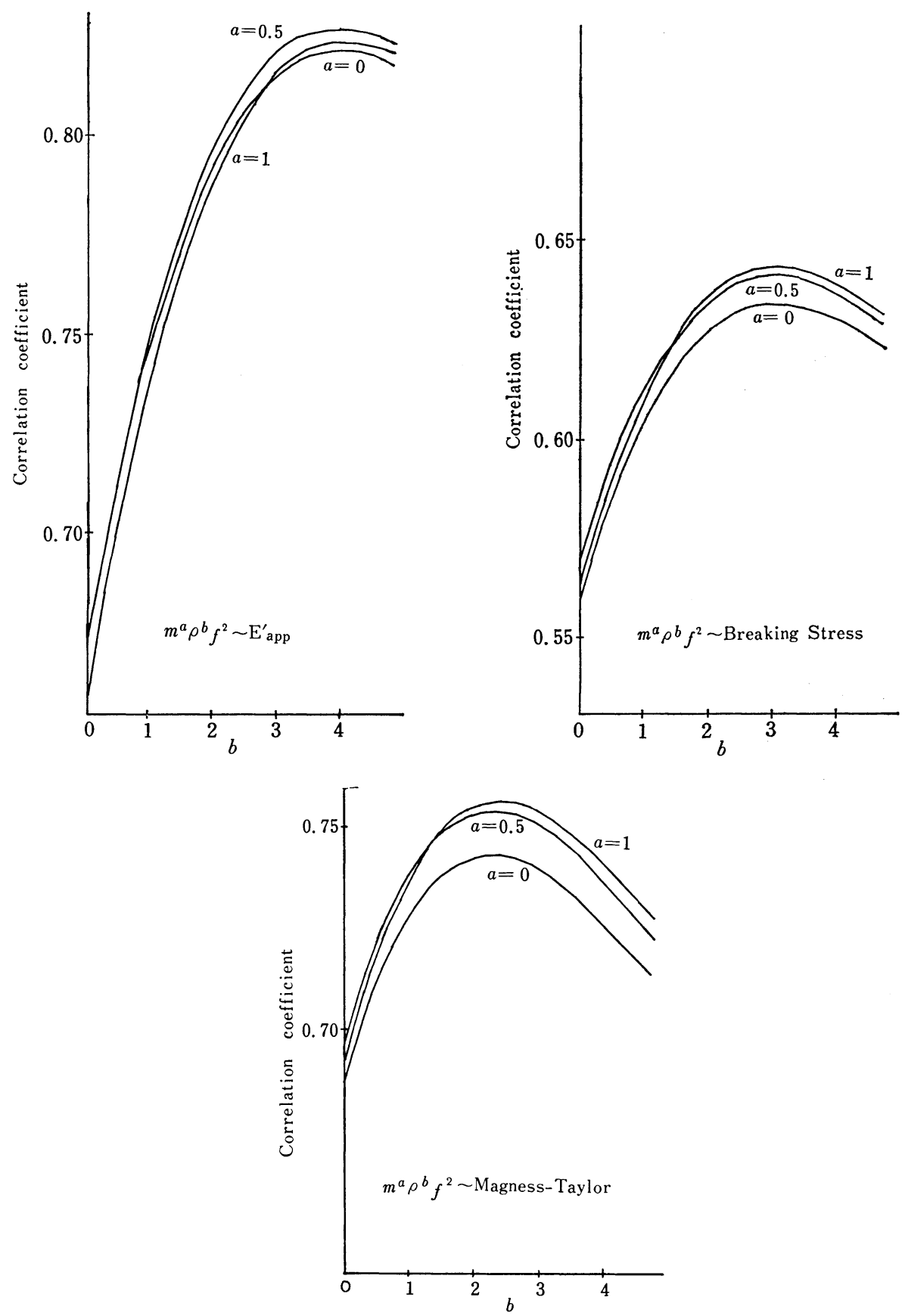

Fig. 8. Variations in the correlation coefficient for all apples as influenced by $a$ and $b$.

$m f^{2}$ and $m^{2 / 3} \rho^{1 / 3} f^{2}$ and had not much theoretical meaning. However, in case of a nonhomogenious horticultural product having an anomalous shape, any model for deriving the index has a gap from the real fruit. Thus from a practical application point of view, it has some meaning to search for a suitable method compensating for $m$ and $\rho$ even without a theoretical model.

Calculating at intervals of 0.25 on both $a$ 


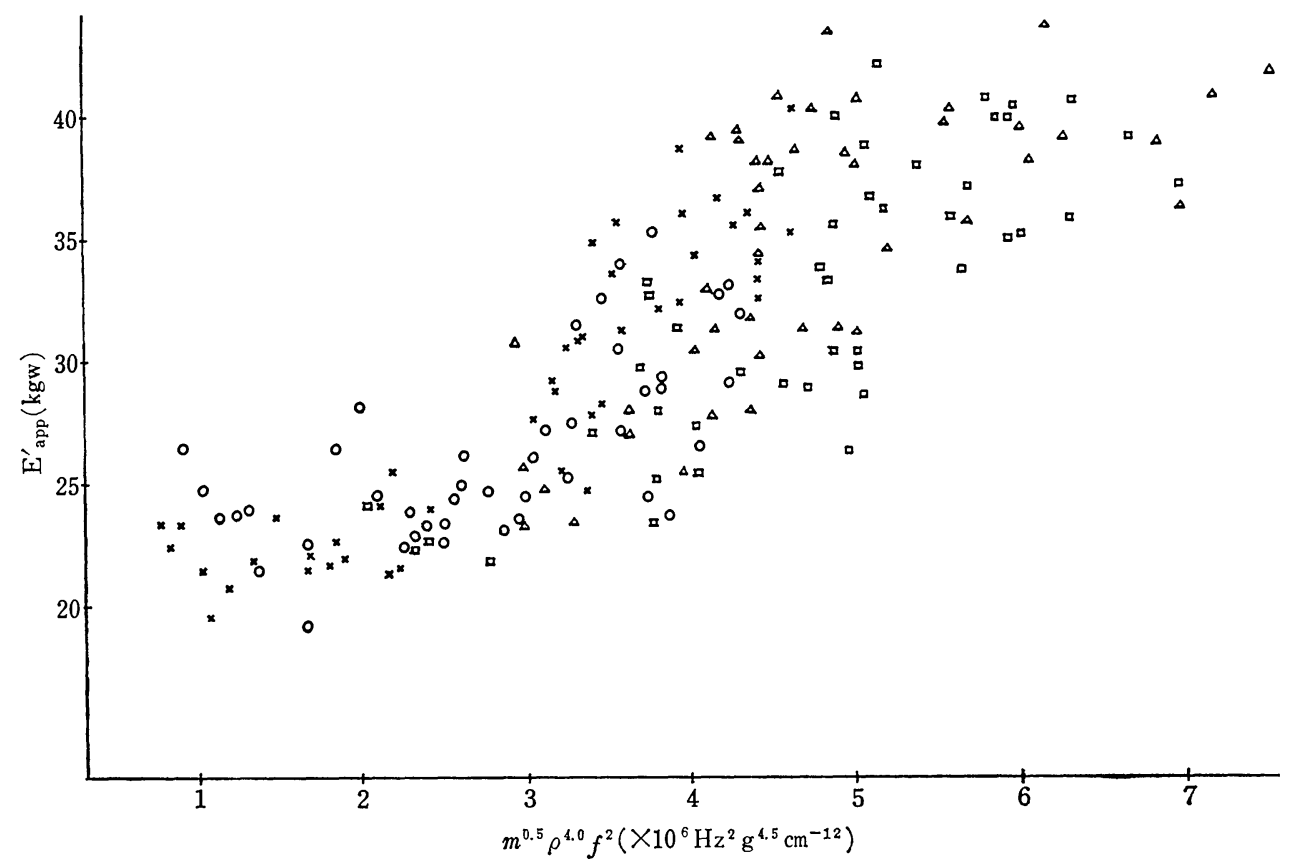

Fig. 9. Scatter diagram of $E_{\text {app }}^{\prime}$ vs. $m^{0.5} \rho^{4.0} f^{2}$ for all apples. $\times \cdots . .$. Nagano Golden Delicious $\triangle \cdots \cdots$ Nagano Starking Delicious O.......Aomori Golden Delicious $\square$......Aomori Starking Delicious

and $b$, the correlation coefficients between $m^{a} \rho^{b} f^{2}$ and internal textural qualities are resulted as shown in Fig. 6 to Fig. 8.

As for watermelons shown in Fig. 6, correlation coefficients are drastically affected by the value of $a$, whereas the value of $b$ has a relatively small effect. This is probably due to the wide distribution of sample weight $(m=3.8-8.1 \mathrm{~kg})$, and vice versa, the small distribution of sample density $(\rho=0.92-0.97$ $\left.\mathrm{g} / \mathrm{cm}^{3}\right)$. The correlation coefficients with $E_{\text {app }}^{\prime}$, breaking stress and sensory firmness have the maximum values of 0.588 (at $a=$ 1. 0, $b=3.5$ ), 0.594 (at $a=0.5, b=3.75$ ), and 0.646 (at $a=0.5, b=1.0$ ), respectively. These show that $a$ value is nearly equal to the previously proposed indices ( $a=1$ or $2 / 3$ ), however, $b$ value is apart from the previously proposed indices $(b=0$ or $1 / 3)$. Considering the small effect of $b$ on the changes in the correlation coefficients, it cannot be asserted that the increased $b$ value has a significant effect. The similar result was obtained for the index $\left(m^{a} \rho^{b} f_{2}^{2}\right)$ using the second peak frequency. Consequently, for watermelons, there are not any indices which correlate to internal textural qualities much better than $m^{2 / 3} \rho^{1 / 3} f^{2}$.

As for apples, on the other hand, Fig. 7 shows the correlation coefficient affected by variable parameter $b$ of acoustic index $m^{a} \rho^{b} f^{2}$ in which the parameter $a$ was fixed to be 0 and 1.0. There was a tendency for the maximum values of correlation coefficients occurring in a region, such as $b$, to be much greater than the previously proposed indices. The only exception was obtained for Nagano Golden Delicious with $m^{a} \rho^{b} f^{2} v s$. sensory firmness. In case of 'Starking Delicious', the correlation coefficients increased steeply with $b$ to show the maximum values in the region of 2.0-5.0, however, there was little increment of correlation coefficients observed for 'Golden Delicious'. This difference between cultivars may be due to the difference of standard deviation in the sample density (Table 2). 
The effect of $a$ on correlation coefficients was not so large as $b$. In most cases the region of $a=0.5-1.0$ which was nearly equal to the previously proposed indices was most effective. Consequently, for apples having a large variance in density such as 'Starking Delicious' in this test, it is recommended to use the index which has more compensation of density than previously proposed indices so that more increased correlation coefficients may be obtained.

The correlation coefficients were calculated for all apples altogether as shown in Fig. 8. The correlation coefficients $m^{a} \rho^{b} f^{2} v s . E_{\text {app }}^{\prime}$, breaking stress and Magness-Taylor test have the maximum values 0.826 (at $a=0.5, b=$ 4.0 ), 0.643 (at $a=0.75, b=3.0$ ) and 0.756 (at $a=1.0, b=2.5$ ), respectively. These values proved to be significantly higher than the corresponding values for previously proposed indices (Table 4). As an example, the relation between $m^{0.5} \rho^{4.0} f^{2}$ and $E^{\prime}{ }_{a p p}$ is shown in Fig. 9. As compared with Fig. 5, increased correlation is observed by using this newly proposed index.

\section{Acknowledgement}

The authors would like to express their thanks to Dr. Hisaya Horiuchi, Dr. Katsuyoshi Nishinari, Mr. Sumio Kawano and Mr. Akira Hayakawa of the National Food Research Institute for their kind advice and assistance.

\section{Literature Cited}

1. BouRNE, M. C. 1966. Measure of Shear Com- pression Components of Puncture Tests. J. Food Sci. $31: 282-291$.

2. BOURne, M. C. 1967. Deformation Testing of Foods. 1. A Precise Technique for Performing the Deformation Test. J. Food Sci. $32: 601-605$.

3. COOKE, J. R. 1972. An Interpretation of the Resonant Behavior of Intact Fruits and Vegetables. Transactions of the ASAE 15 : 1075-1080.

4. Finney, E. E. 1969. To Define Texture in Fruits and Vegetables. Agr. Eng. $50: 462-$ 465.

5. FinNEY, E. E. 1970. Mechanical Resonance within Red Delicious Apples and Its Relation to Fruit Texture. Transactions of the ASAE $13: 177-180$.

6. Finney, E. E. 1971. Dynamic Elastic Properties and Sensory Quality of Apple Fruit. J. Texture Studies $2: 62-74$.

7. FinNEY, E.E. 1972. Vibration Techniques for Testing Fruit Firmness. J. Texture Studies $3: 262-283$.

8. Finney, E. E., J. A. ABbott., A. E. WATAdA and D. R. MASSIE. 1978. Nondestructive Sonic Resonance and the Texture of Apples. J. Amer. Soc. Hort. Sci. 103 : 158-162.

9. MOHSEnin, N. N., H. E. COOPER and L. D. TUKEY. 1963. Engineering Approach to Evaluating Textural Factors in Fruits and Vegetables. Transactions of the ASAE $6: 85-88,92$.

10. YAMAMOTO, H., M. IWAMOTO and S. HaginUma. 1980. Acoustic Impulse Respnse Method for Measuring Natural Frequency of Intact Fruits and Preliminary Applications to Internal Quality Evaluations of Apples and Watermelons. J. Texture Studies $11: 117-136$.

\title{
リンゴ・スイカの音響インパルス応答法（打音）による非破壊品質測定 \\ 山本 博道・岩元 睦夫 ·萩沼 之孝 （農林水産省食品総合研究所）
}

\begin{abstract}
摘要
リンゴ・スイカの内部品質の非破壞測定法として, 打 音から求められた固有振動数, 及びそれを試料の質量・ 密度で補正した指標と破壊試験（一定速度での圧縮試験 及び官能試験)により求められた果肉硬度との関係を検

討した. 打音から求められた指標, みかけのヤング率, 破壊ひずみ, 及び, 官能試験での果肉硬度の評点の間に は, 高い相関関係が認められた。リンゴの外観から専門 家により，3区分された熟度クラス間には, 果肉硬度の
\end{abstract}


有意差は認められず，外観からの内部品質評価の限界が 明らかにされた.リンゴについては，これまでに提案さ れた指標よりも, 密度についての補正を, より大きくし た指標を用いる方が，内部品質との相関係数が大きくな
ることが認められた．本法は，非破壊品質測定法として 有用であり，振動励起法に比較して，単純であることが 実用上の利点である. 